\title{
Paleomagnetism of the late Quaternary Ontake Volcano, Japan: directions, intensities, and excursions
}

\author{
Hidefumi Tanaka ${ }^{1}$ and Takehiko Kobayashi ${ }^{2}$ \\ ${ }^{1}$ Faculty of Education, Kochi University, Kochi 780-8520, Japan \\ ${ }^{2}$ Faculty of Science, Toyama University, 3190 Gofuku, Toyama 930, Japan
}

(Received August 14, 2002; Revised March 12, 2003; Accepted March 31, 2003)

\begin{abstract}
Study of paleosecular variation was carried out to mostly andesite lavas from the late Quaternary Ontake Volcano which have detailed stratigraphy and accurate radiometric ages. Among 42 sites, some of the results from lava successions were combined due to possible equivalent ages, remaining 35 sites. After excluding two low latitude VGPs, angular dispersion of $15.6^{\circ}$ was obtained for a period which is accurately confined between $20 \mathrm{ka}$ and $90 \mathrm{ka}$. The obtained angular dispersion is not different from the typical value for the last $5 \mathrm{my}$, and this is not surprising if we consider that the global paleointensity was not necessarily low and rather oscillatory during the period of 40$100 \mathrm{ka}$ which precedes the global low in 20-40 ka. Two low latitude VGPs from $48 \mathrm{ka}$ lava $\left(41.9^{\circ} \mathrm{N}, 196.2^{\circ} \mathrm{E}\right)$ and 80 ka lava $\left(15.9^{\circ} \mathrm{N}, 183.3^{\circ} \mathrm{E}\right)$ indicate existence of excursions in Japan during the latest Pleistocene. Preliminary paleointensity experiments indicate that the $80 \mathrm{ka}$ excursion is accompanied by a low paleointensity of about $5 \mu \mathrm{T}$ while the $48 \mathrm{ka}$ one is not. These two excursions are probably related to those reported previously not only from the Ontake Volcano and its proximity but also from other several sites in Japan, although they were not conclusive. The $48 \mathrm{ka}$ excursion probably correlates to the Laschamp excursion. This is consistent with the fact that the VGP position from the $48 \mathrm{ka}$ lava comes to the central Pacific region, similar to those from the Laschamp excursion found in New Zealand. Possible correlation of the $80 \mathrm{ka}$ excursion is the one from Norwegian-Greenland Sea and Arctic Ocean, which are stratigraphically between the Laschamp and the Blake excursions.
\end{abstract}

Key words: Paleosecular variation, paleointensity, Ontake Volcano, excursion, Laschamp, Blake.

\section{Introduction}

Paleosecular variation (PSV) from lavas has often been used as a statistical indication of the past geodynamo activity. Angular standard deviation (ASD) is usually used as a measure of angular dispersion in the positions of the virtual geomagnetic pole (VGP). One of the established features of the past geomagnetic field is that ASD of VGP becomes larger when observed at higher latitude (McElhinny and McFadden, 1997).

Although the standard latitude variation curve of ASD is well established for the recent geological time, its dependency on the longitude of the observation site is still controversial. Hypothesis of the Pacific Non-dipole Low is a long-standing issue (ex., Shibuya et al., 1995; McElhinny et al., 1996). There are some anisotropic PSV models which propose longitude dependent ASD (ex., Tsunakawa, 1988; Constable and Johnson, 1999). Hence, it is always important to add a new study from wide area of the world (ex., Yamamoto et al., 2002). This paper reports a PSV study from 41 lavas from Japan of late Quaternary age, together with preliminary results of paleointensity experiments made to several selected lavas.

Quite a few excursions have been reported in the Brunhes chron (Lund et al., 1998), although there are only few of them which have been established as a global feature of the

Copy right(C) The Society of Geomagnetism and Earth, Planetary and Space Sciences (SGEPSS); The Seismological Society of Japan; The Volcanological Society of Japan; The Geodetic Society of Japan; The Japanese Society for Planetary Sciences. geomagnetic field. Identification of an excursion in lava flows would be a strong evidence to its existence because possibility of data artifacts is much smaller in the remanence of volcanic rocks which originates from a thermoremanent magnetization (TRM). This study also reports excursions found from two lava flows of $48 \mathrm{ka}$ and $80 \mathrm{ka}$.

\section{Geology and Sampling}

The Ontake Volcano is a member of the Norikura Volcanic Zone in central Japan, and forms a composite volcano reaching the maximum altitude over $3 \mathrm{~km}$. Detailed summary of stratigraphy and petrology was given by Yamada and Kobayashi (1988). Volcanic products of the Ontake Volcano are mostly lavas and pyroclastics of andesite including minor rhyolite, dacite and basalt. Its edifice consists of two compound volcanoes with clear erosional gap between them, which are called the Older and Younger Ontake. Prolonged cessation of volcanism has been suggested between the two volcanoes, and a recent geochronological study using $\mathrm{K}-\mathrm{Ar}$ dating by Matsumoto and Kobayashi $(1995,1999)$ revealed the detailed history of the Older and Younger Ontake. The Older Ontake Volcano was formed during the period between 750 and $420 \mathrm{ka}$. Long period of subdued volcanism succeeded lasting over $300 \mathrm{ky}$, and the edifice of the volcano was heavily eroded leaving the total volume of volcanic products amounting to about $40 \mathrm{~km}^{3}$. At about 80-90 ka volcanism restarted to form the Younger Ontake Volcano which added volcanic products of another $40 \mathrm{~km}^{3}$ and finally formed the 


\begin{tabular}{|c|c|c|c|c|c|c|c|c|c|c|c|c|}
\hline & \multicolumn{11}{|c|}{ K-Ar age (ka) } \\
\hline & & 0 & 10 & 20 & 30 & 40 & 50 & 60 & 70 & 80 & 90 & 100 \\
\hline \multirow{8}{*}{ 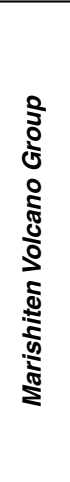 } & Sannoike Vol. & & \multicolumn{2}{|c|}{$\longrightarrow$} & -1 & 1 & i & 1 & 1 & i & 1 & i \\
\hline & Yonnoike Vol. & & 1 & 1 & & $\overline{2}$ & 1 & ; & 1 & 1 & 1 & I \\
\hline & Ichinoike Vol. & & $\begin{array}{l}1 \\
1\end{array}$ & & $\frac{1}{10}$ & 1 & $\begin{array}{l}1 \\
1\end{array}$ & $\begin{array}{l}1 \\
1\end{array}$ & $\begin{array}{l}1 \\
1\end{array}$ & $\begin{array}{l}1 \\
1\end{array}$ & 1 & i \\
\hline & Mamakodake Vol. & & 1 & 1 & 1 & & & ; & i & 1 & 1 & i \\
\hline & Kusakidani Vol. & & 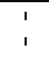 & $\begin{array}{l}2 \\
1\end{array}$ & 1 & 1 & & 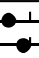 & $\frac{1}{1+}$ & $\begin{array}{l}1 \\
1\end{array}$ & $\begin{array}{l}2 \\
1\end{array}$ & ; \\
\hline & Okunoin Vol. & & 1 & 1 & 1 & i & 1 & $\frac{1}{1}$ & $\frac{1}{1}$ & 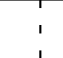 & 1 & ! \\
\hline & Kongodo Vol. & & 1 & 1 & 1 & 1 & 1 & $\rightarrow$ & 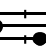 & 1 & $\begin{aligned} 1 \\
-1\end{aligned}$ & ' \\
\hline & Nigorigo Vol. & & $\begin{array}{l}1 \\
1\end{array}$ & $\begin{array}{l} \\
1\end{array}$ & $\begin{array}{l}1 \\
1\end{array}$ & $\begin{array}{l}1 \\
1\end{array}$ & $\begin{array}{l}1 \\
1\end{array}$ & $\begin{array}{l}1 \\
1\end{array}$ & $\frac{1}{1}$ & & $\begin{array}{l}1 \\
1 \\
\end{array}$ & 1 \\
\hline \multirow{4}{*}{ 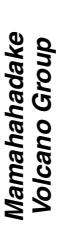 } & Miureyama Lava & & i & 1 & 1 & i & 1 & i & T & $\frac{1}{1}$ & & -1 \\
\hline & NigoridakiP.F.D. & & 1 & $\begin{array}{l}2 \\
1\end{array}$ & 1 & $\begin{array}{l}1 \\
1\end{array}$ & $\begin{array}{l}1 \\
1\end{array}$ & ' & 1 & \multicolumn{2}{|c|}{$\stackrel{1}{1}$} & 1 \\
\hline & Yunotani Lava & & i & 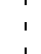 & 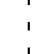 & i & 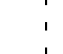 & 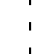 & 1 & \multicolumn{2}{|c|}{$\underset{1}{1 \rightarrow 1}$} & t \\
\hline & Shintani Lava & & i & 1 & 1 & 1 & 1 & ; & 1 & $\frac{1}{1}$ & -1 & ! \\
\hline
\end{tabular}

Fig. 1. Highly correlated radiometric age and stratigraphy for the lava flows from the Younger Ontake Volcano. This figure was reproduced from figure 5 of Matsumoto and Kobayashi (1995) with permission from Elsevier Science, although a minor correction was made in stratigraphy. In the original figure, stratigraphy of two volcanoes was erroneously placed. Stratigraphic position of Yonnoike Volcano is higher than Ichinoike Volcano although inconsistent relation of the K-Ar ages is observed between them. Note that within a specific volcano the data points were ordered by age because no stratigraphic relation is known among each lava flows.

present-day shape of stratovolcano.

Activity of the Younger Ontake Volcano started with eruption of huge volume of rhyolite pumice-falls, resulting in the formation of an extensive tephra layer called "Pm-I" which covers a wide area of central Japan. Eruption of dacitic products followed and resulted in the formation of a composite volcano. This earlier stage of the Younger Ontake is called Mamahahadake Volcano Group. Next stage of volcanism started with an abrupt change of petrology and resulted in the formation of series of small stratocones of andesitic products which are overlapped each other and make up the summit of the present Ontake Volcano. This later stage is called Marishiten Volcano Group. Activity of the Marishiten Volcano Group ended at about $20 \mathrm{ka}$, and following inactive period includes only superficial phenomena with the most recent phreatic explosion of 1979. Matsumoto and Kobayashi (1995) gave an excellent correlation between the newly obtained K-Ar dating and the volcano-stratigraphy as shown in Fig. 1. This figure was reproduced from Matsumoto and Kobayashi (1995) with a minor correction because stratigraphic order of two volcanoes was erroneously placed in the original figure. Stratigraphic position of Yonnoike Volcano is higher than Ichinoike Volcano although inconsistent relation of the K-Ar ages is observed between them. Nevertheless, accuracy of K-Ar ages are well illustrated in Fig. 1.

Samples collected in this study are from andesite lavas from the Younger Ontake which are found at both summit and mountainside. Sampling localities and associated K-Ar ages are included in Table 1 which summarizes all paleomagnetic results in this study and the K-Ar ages by Matsumoto and Kobayashi (1995). Although most of the K-Ar ages are not necessarily from the specific flows collected in this study, they should represent fairly accurately the ages of the lavas collected.

A portable drill was used to collect core samples and a sun compass was used for orientation. Difference of magnetic azimuth, used when sun is not available, from the sun azimuth is usually less than $2-5^{\circ}$. Any tilt correction was not made to the measured remanence directions because no local tectonic disturbance was observed throughout the sites sampled.

\section{Measurements of Paleodirections}

Six to eight cores were usually collected at each site, and alternating field (AF) and thermal demagnetizations were progressively applied to at least one sample for each site. When determination of the characteristic remanence is straightforward, only AF demagnetization was applied to the rest of the cores and progressive demagnetization was stopped when the stable component was confirmed as a set of data pointing to the origin on the orthogonal plot.

Most samples have a stable characteristic remanence with only moderately small secondary components which are easily cleaned by AF or thermal demagnetization. Typical orthogonal plots of $\mathrm{AF}$ and thermal demagnetizations are shown in Fig. 2(a,b) and (c,d), respectively.

Although defining a characteristic remanence is straightforward for most lavas, there were seven problematic sites which apparently suffered from lightning strikes. Possible lightning strikes at these sites are easily known by very large NRM intensities, and this is consistent with the fact that the site localities were at the summit of high altitude. In some samples, the remanence direction moved along a great circle with progressive demagnetization as shown in Fig. 2(e), and the characteristic remanence $(\mathrm{Chrm})$ was never revealed by both $\mathrm{AF}$ and thermal methods. In most cases, however, the 


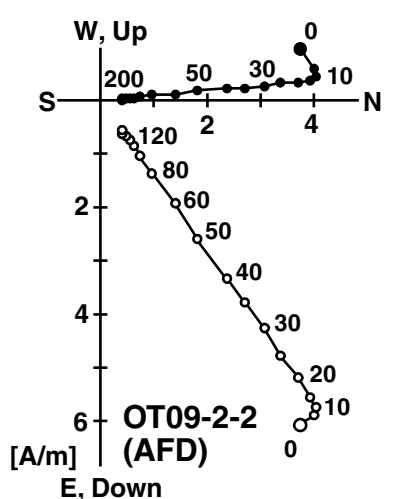

(a)

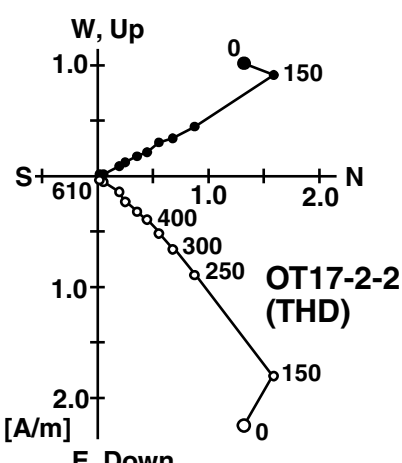

(c)

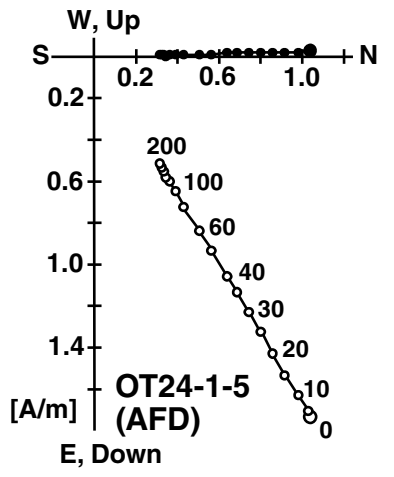

(b)

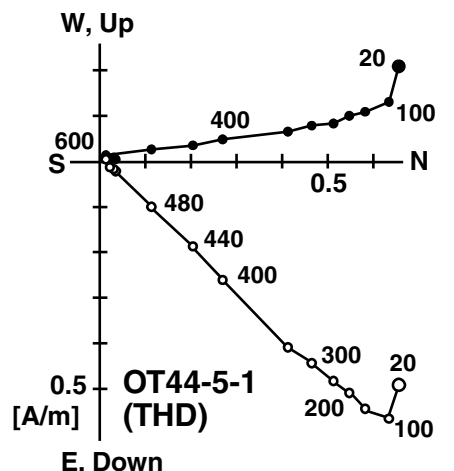

(d)

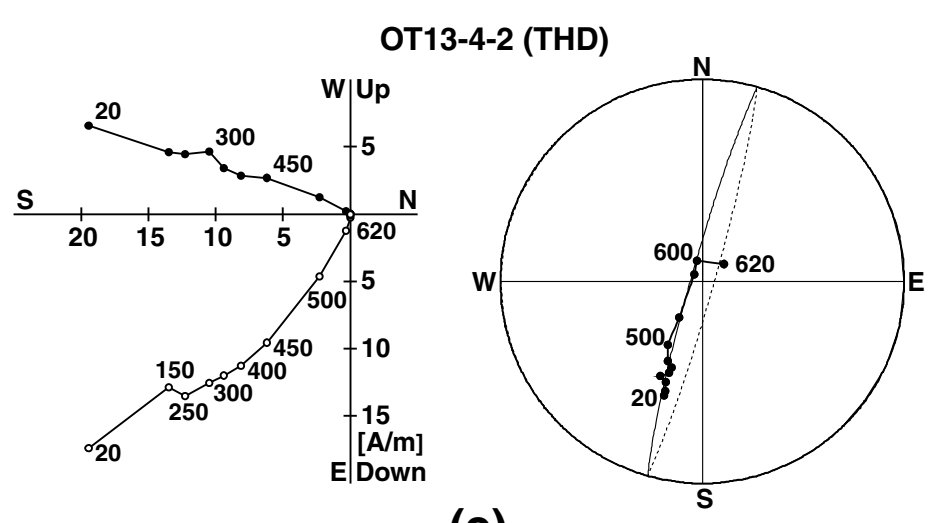

(e)

Fig. 2. Typical orthogonal plots of progressive AF (a,b) and thermal (c,d) demagnetizations. Samples are andesite lava except for OT24 (b) which is a rare case of a rhyolite lava. An example of orthogonal plot and corresponding equal area plot of thermal demagnetization are shown in (e) for a problematic site which apparently suffered from a lightning strike. Application of the method of McFadden and McElhinny (1988) to the combined great circles and linear data was successful in most cases.

site mean direction was successfully obtained from the combination of the great circles and linear data by the method of McFadden and McElhinny (1988). Exceptions were two sites in which the results were finally rejected due to a large error $\left(\alpha_{95}>20^{\circ}\right)$.

Intermediate directions were found at three sites from two lava flows of $48 \mathrm{ka}$ and $80 \mathrm{ka}$. Representative orthogonal plots of $\mathrm{AF}$ and thermal demagnetizations are shown in Fig. 3 for the $48 \mathrm{ka}(\mathrm{a}, \mathrm{b})$ and $80 \mathrm{ka}(\mathrm{c}-\mathrm{f})$ lavas. Stability of the remanence to both $\mathrm{AF}$ and thermal demagnetizations indicates the primary origin of these anomalous paleodirections. There are three exceptions among 19 samples from the $80 \mathrm{ka}$ lava, one of which is shown in Fig. 3(f). Inconsistent remanence direction of OT33-8-1 is probably of secondary origin because of abnormally high remanence intensity and its rapid decrease with progressive AF demagnetization. This is also supported by the fact that the three inconsistent remanence directions were found from a limited part of the outcrop. Hence, these three directions were discarded.

Equal area plot of sample directions are shown in Fig. 4 for the $48 \mathrm{ka}$ and $80 \mathrm{ka}$ lavas, where the larger circle indicates the site mean direction. The anomalous paleodirection of the $48 \mathrm{ka}$ lava is certain because they were obtained from two distinct sites which are $200 \mathrm{~m}$ apart. The paleodirec- 

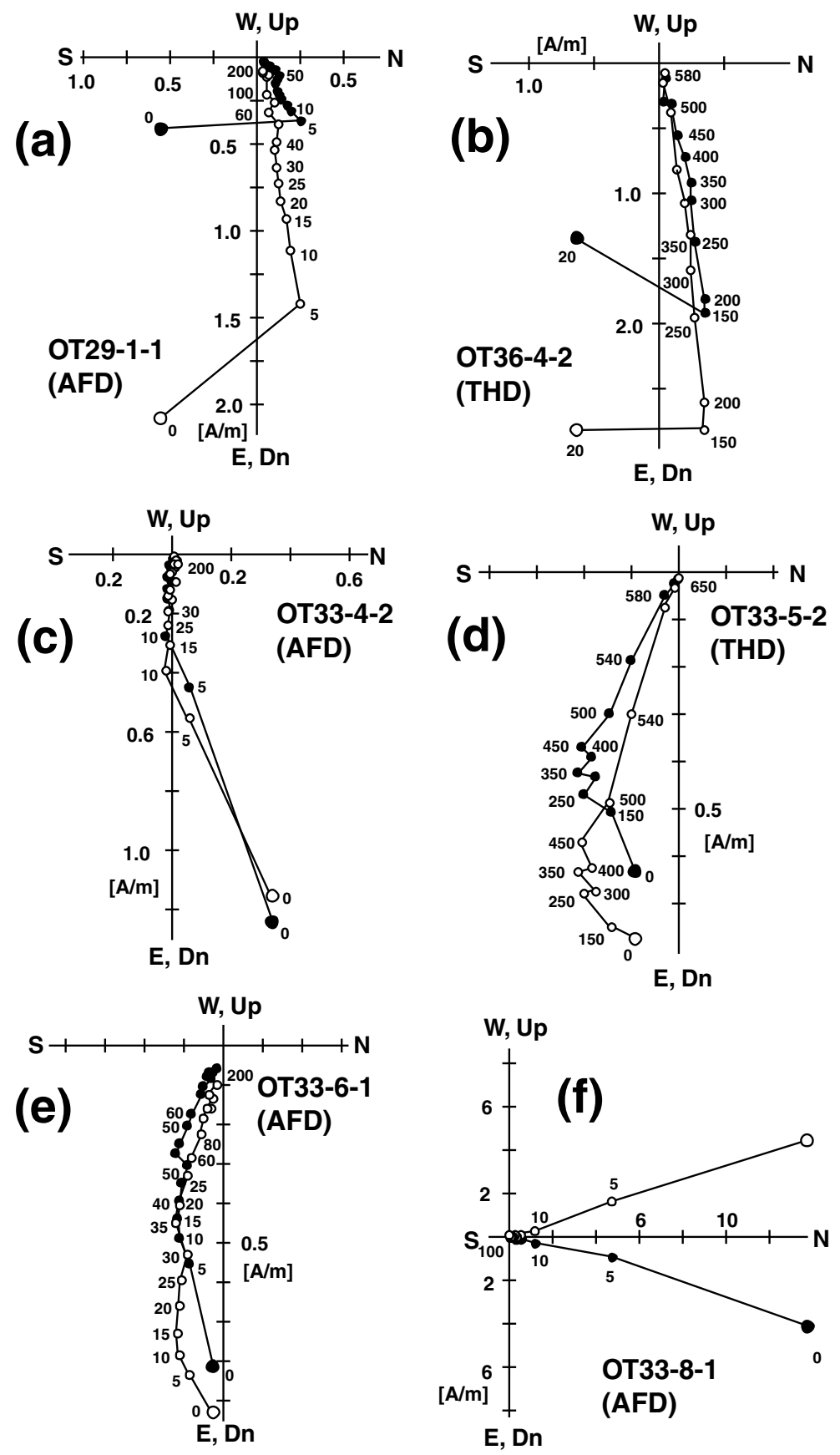

Fig. 3. Examples of orthogonal plot of progressive thermal and AF demagnetizations to the $48 \mathrm{ka}(\mathrm{a}, \mathrm{b})$ and $80 \mathrm{ka}(\mathrm{c}-\mathrm{f})$ lavas, which give intermediate paleodirections. The remanence of OT33-8-1 shown in (f) was judged to be of secondary origin due to its rapid decrease and much stronger NRM intensity.
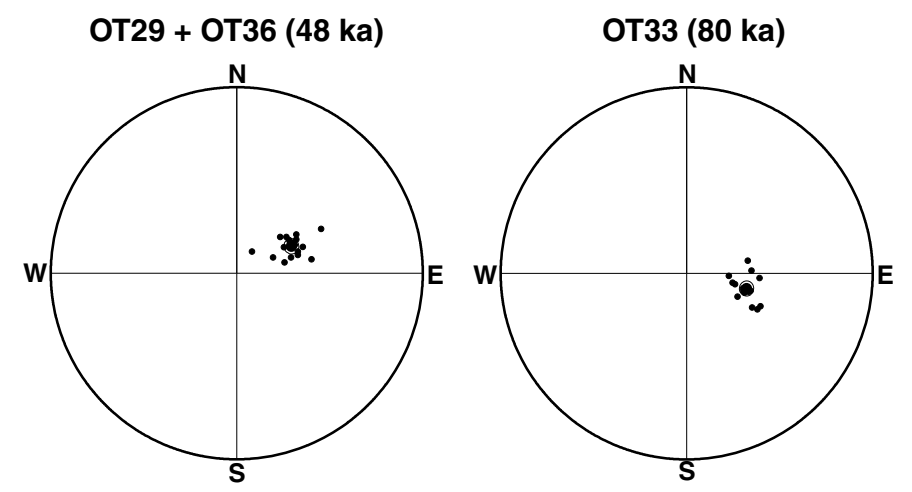

Fig. 4. Equal area plots of sample directions for the $48 \mathrm{ka}$ and $80 \mathrm{ka}$ lavas which indicate existence of two excursions in Japan in the latest Pleistocene. The site mean direction is shown by a larger symbol with a circle of $95 \%$ confidence. 


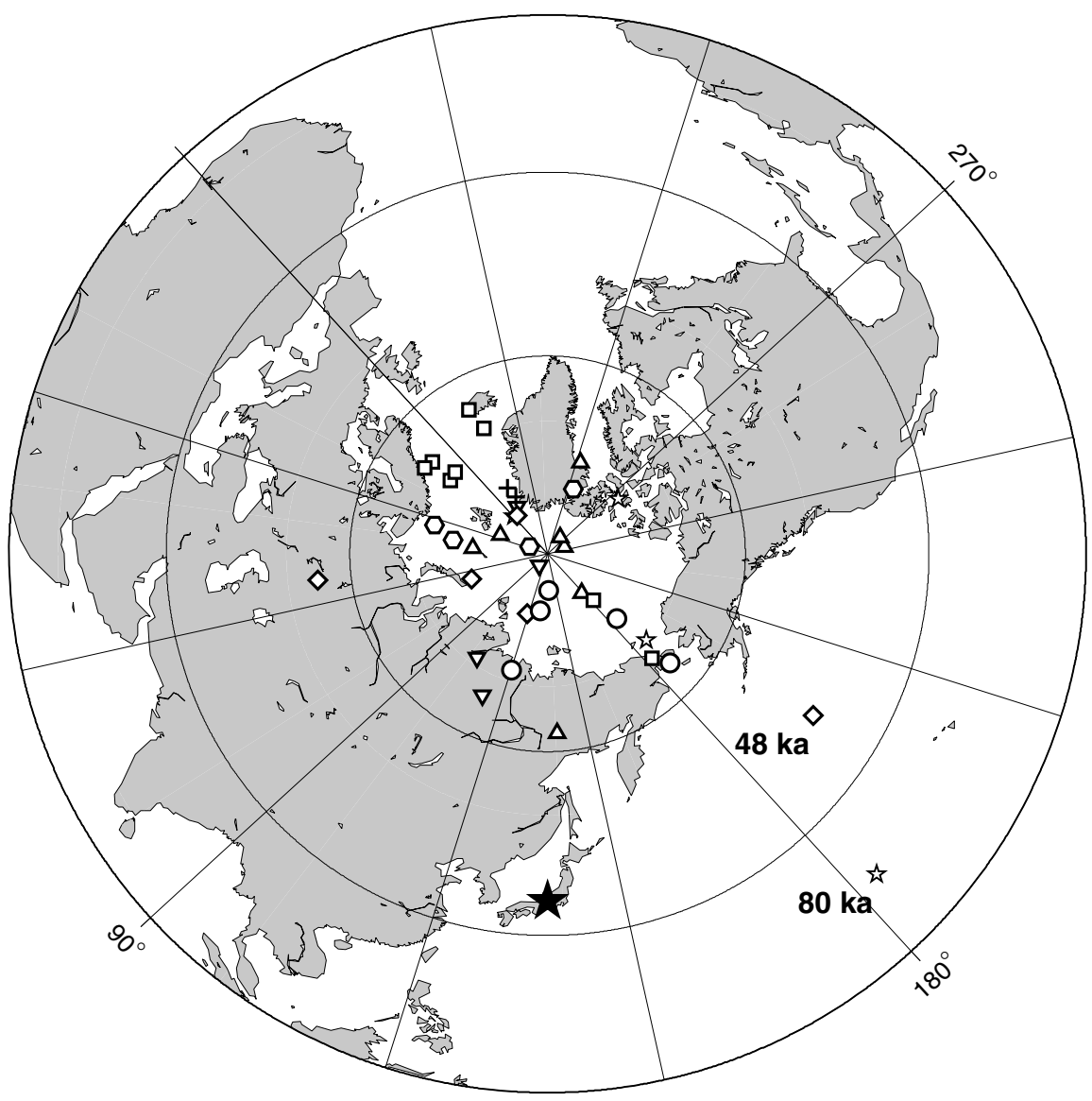

Fig. 5. Equal area plot of VGPs from all sites with different symbols for each age group. Cross, Sannoike Volcano (21 \pm 5 ka); circle, Ichinoike Volcano ( $29 \pm 5 \mathrm{ka}$ ); hexagonal, Yonnoike Volcano ( $36 \pm 3 \mathrm{ka}$ ); diamond, Mamakodake Volcano (48 $\pm 4 \mathrm{ka})$; square, Kusakidani Volcano (58 $\pm 11 \mathrm{ka})$; triangle, Okunoin Volcano (59 $\pm 7 \mathrm{ka})$; inverted triangle, Kongodo Volcano (66 $\pm 5 \mathrm{ka})$; star, four lavas for 80-84 ka. Large closed star indicates the site location. Note two low latitude VGPs which are excursions at $48 \mathrm{ka}$ and $80 \mathrm{ka}$.

tion of the $80 \mathrm{ka}$ lava should also be certain because two outcrops which are $20 \mathrm{~m}$ apart across a gully gave the same results. These intermediate directions are characterized by easterly deflected declination, and their implications will be discussed later. Site mean directions with Fisher statistics (Fisher, 1953) are summarized in Table 1 for total of 40 sites remained and an equal area plot of VGPs is shown in Fig. 5.

Taking advantage of accurate ages assigned to each lava group, it is worth examining whether any long term temporal change could be recognized in the paleodirections shown in Fig. 5. There are some groupings of the VGP position according to the age group; five VGPs from Ichinoike Volcano (29 ka, open circle) locate at the Pacific side from the north pole while four VGPs from Yonnoike Volcano (36 ka, open hexagonal) come to the Atlantic side. However, this is probably not significant because of too small sample number for each group. In fact, two of eight VGPs from Kusakidani Volcano (58 ka, open square) are much different in their position from the rest. Hence, the different VGP positions from lava groups of different age merely indicates rather short time span covered by the lava group. Nevertheless, taking altogether, the data constitute a set of VGPs which are scattered fairly evenly around the north pole as seen in Fig. 5 .

Three lava groups taken at the summit are from lava successions of 5 to 8 flows. There are some suggestions from combined studies of paleomagnetism and radiometric dat- ing that lava successions are often formed in a short time span (ex., Mankinen et al., 1986). Taking this fact in mind, paleomagnetic results with similar directions are combined when the data come from the same volcano (not necessarily from a lava succession). Statistical test by McFadden and Lowes (1981) was used with a level of significance of $5 \%$. There are only two cases in which combining site mean directions was necessary; four successive lava flows from Kusakidani Volcano (58 ka) and two lava flows of proximity of site location from Sannoike Volcano (21 ka). Data was combined from the beginning for the two intermediate directions (OT29, OT36) because they are from the same flow.

After merging some of the individual data, there remained 35 paleodirections including two possible excursions. When these two excursions are excluded, the mean VGP and the mean field direction are $\left(86.8^{\circ} \mathrm{N}, 78.5^{\circ} \mathrm{E}\right)$ with $A_{95}=5.0^{\circ}$ and $\left(\mathrm{I}=55.5^{\circ}, \mathrm{D}=356.0^{\circ}\right)$ with $\alpha_{95}=4.3^{\circ}$, respectively. On the other hand, the ASD for VGP was $15.6^{\circ}$ with lower and upper confidence limits by $\operatorname{Cox}(1969,1977)$ of $13.3^{\circ}$ and $18.9^{\circ}$, respectively. These values are after correction of the mean within-site dispersion of $7.5^{\circ}$ for the mean sample number of 6.9. The obtained ASD values are consistent with the typical values for the last $5 \mathrm{my}$ (McElhinny and McFadden, 1997).

The two paleodirections which were excluded from estimation of ASD are considered to represent excursions be- 
Table 1. Site mean paleodirections from the Younger Ontake Volcano.

\begin{tabular}{|c|c|c|c|c|c|c|c|c|c|c|c|}
\hline Site & $\begin{array}{l}\text { Lat } \\
\left({ }^{\circ} \mathrm{N}\right)\end{array}$ & $\begin{array}{l}\text { Lon } \\
\left({ }^{\circ} \mathrm{E}\right)\end{array}$ & Inc & Dec & $\alpha_{95}$ & $\mathrm{~N}$ & $\begin{array}{l}\text { Plat } \\
\left({ }^{\circ} \mathrm{N}\right)\end{array}$ & $\begin{array}{l}\text { Plon } \\
\left({ }^{\circ} \mathrm{E}\right)\end{array}$ & $\begin{array}{c}\bar{J} \\
(A / m)\end{array}$ & $\begin{array}{c}s_{J} \\
(A / m)\end{array}$ & Remark \\
\hline \multicolumn{12}{|c|}{ 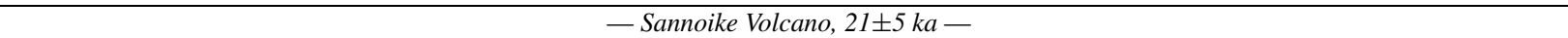 } \\
\hline OT44 & 35.905 & 137.491 & 44.1 & 353.3 & 1.6 & 6 & 78.4 & 349.0 & 1.3 & 0.3 & \\
\hline OT45 & 35.904 & 137.489 & 45.8 & 354.6 & 2.3 & 6 & 80.2 & 346.8 & 1.1 & 0.4 & \\
\hline \multicolumn{2}{|c|}{ OT44+OT45 } & & 44.9 & 353.9 & 1.3 & 12 & 79.2 & 348.1 & & & $\dagger$ \\
\hline \multicolumn{12}{|c|}{ - Ichinoike Volcano, $29 \pm 5 \mathrm{ka}$ (lava succession except OT46) - } \\
\hline OT07 & 35.892 & 137.479 & 60.7 & 44.4 & 34.9 & 8 & - & - & 76 & 49 & $\ddagger$, $*$ \\
\hline OT05 & 35.893 & 137.483 & 63.0 & 358.5 & 4.7 & 6 & 81.4 & 130.3 & 3.3 & 2.0 & \\
\hline OT04 & 35.893 & 137.483 & 69.4 & 351.2 & 2.8 & 8 & 71.7 & 120.4 & 3.0 & 0.8 & \\
\hline OT02 & 35.893 & 137.483 & 66.7 & 28.7 & 12.2 & 6 & 65.2 & 185.9 & 2.5 & 0.2 & \\
\hline OT03 & 35.893 & 137.483 & 60.4 & 0.2 & 4.1 & 9 & 84.5 & 139.1 & 4.2 & 1.9 & \\
\hline OT46 & 35.900 & 137.492 & 63.2 & 14.6 & 2.3 & 6 & 75.8 & 184.6 & 3.6 & 1.5 & \\
\hline \multicolumn{12}{|c|}{ - Yonnoike Volcano, $36 \pm 3 \mathrm{ka}-$} \\
\hline OT28 & 35.918 & 137.460 & 52.0 & 343.0 & 2.3 & 7 & 75.6 & 39.1 & 2.0 & 0.2 & \\
\hline OT41 & 35.910 & 137.486 & 49.0 & 340.2 & 3.6 & 6 & 72.4 & 33.2 & 4.9 & 2.2 & \\
\hline OT42 & 35.910 & 137.486 & 54.2 & 356.7 & 5.0 & 6 & 87.1 & 24.8 & 2.9 & 2.7 & \\
\hline OT43 & 35.910 & 137.486 & 44.5 & 4.3 & 2.9 & 6 & 79.6 & 295.6 & 1.9 & 0.4 & \\
\hline \multicolumn{12}{|c|}{ - Mamakodake Volcano, $48 \pm 4 \mathrm{ka}$ - } \\
\hline OT29 & 35.937 & 137.464 & 65.0 & 63.4 & 4.6 & 12 & 42.6 & 193.4 & 5.3 & 7.1 & \\
\hline OT36 & 35.936 & 137.464 & 60.0 & 64.4 & 4.1 & 6 & 40.4 & 201.1 & 13 & 24 & (1) \\
\hline \multicolumn{3}{|c|}{ ОТ29+ОT36 } & 63.3 & 63.8 & 3.3 & 18 & 41.9 & 196.2 & & & $\dagger$ \\
\hline OT31 & 35.952 & 137.509 & 49.2 & 354.7 & 2.9 & 7 & 82.6 & 356.1 & 3.3 & 1.3 & \\
\hline OT35 & 35.950 & 137.462 & 58.2 & 345.4 & 1.1 & 6 & 78.0 & 66.0 & 1.2 & 0.3 & \\
\hline ОТ39 & 35.922 & 137.550 & 63.3 & 355.7 & 3.8 & 6 & 80.5 & 118.7 & 2.2 & 0.2 & \\
\hline OT40 & 35.988 & 137.531 & 51.6 & 317.4 & 4.3 & 6 & 54.8 & 54.1 & 7.9 & 2.1 & \\
\hline \multicolumn{12}{|c|}{ - Kusakidani Volcano, $58 \pm 11$ ka (lava succession) - } \\
\hline OT15 & 35.901 & 137.480 & 66.8 & 24.4 & 5.3 & 7 & 67.7 & 182.6 & 29 & 19 & \\
\hline OT16 & 35.901 & 137.480 & 61.4 & 9.4 & 5.3 & 7 & 80.2 & 182.3 & 40 & 43 & $\ddagger$ \\
\hline OT17 & 35.901 & 137.480 & 37.0 & 341.6 & 4.3 & 7 & 67.8 & 9.0 & 2.1 & 0.4 & \\
\hline OT18 & 35.901 & 137.480 & 37.9 & 340.2 & 2.7 & 7 & 67.4 & 12.6 & 8.6 & 8.0 & \\
\hline OT19 & 35.901 & 137.480 & 41.4 & 344.1 & 2.5 & 8 & 71.7 & 10.4 & 13 & 19 & $\ddagger$ \\
\hline OT20 & 35.901 & 137.480 & 39.8 & 345.0 & 4.6 & 8 & 71.4 & 6.0 & 2.6 & 1.5 & \\
\hline \multicolumn{3}{|c|}{ OT17-OT20 } & 39.0 & 342.7 & 3.0 & 4 & 69.5 & 9.5 & & & $\dagger$ \\
\hline OT22 & 35.902 & 137.485 & 25.7 & 348.0 & 8.5 & 7 & 65.2 & 346.2 & 37 & 48 & $\ddagger$ \\
\hline OT21 & 35.902 & 137.485 & 30.7 & 350.2 & 2.8 & 8 & 68.8 & 344.3 & 1.7 & 0.2 & \\
\hline \multicolumn{12}{|c|}{ — Okunoin Volcano, $59 \pm 7$ ka (lava succession) - } \\
\hline OT14 & 35.883 & 137.483 & 53.7 & 346.3 & 3.5 & 7 & 78.7 & 43.1 & 9.1 & 3.4 & \\
\hline OT13 & 35.883 & 137.483 & 75.7 & 3.1 & 4.9 & 8 & 62.8 & 140.6 & 15 & 17 & $\ddagger$ \\
\hline OT12 & 35.883 & 137.483 & 52.2 & 351.6 & 13.6 & 8 & 82.4 & 26.0 & 19 & 17 & $\ddagger$ \\
\hline OT11 & 35.883 & 137.483 & 54.3 & 3.1 & 4.3 & 6 & 87.3 & 249.2 & 6.4 & 2.3 & \\
\hline OT10 & 35.883 & 137.483 & 60.6 & 6.9 & 2.7 & 7 & 82.2 & 178.7 & 8.7 & 5.4 & \\
\hline ОТ09 & 35.883 & 137.483 & 52.8 & 2.3 & 4.4 & 8 & 86.9 & 279.8 & 4.7 & 3.3 & \\
\hline OT08 & 35.883 & 137.483 & 39.0 & 5.3 & 12.7 & 8 & 75.4 & 297.6 & 2.4 & 2.5 & \\
\hline \multicolumn{12}{|c|}{ — Kongodo Volcano, $66 \pm 5 \mathrm{ka}-$} \\
\hline OT24 & 35.874 & 137.554 & 57.0 & 358.4 & 1.4 & 7 & 87.8 & 101.3 & 2.6 & 0.6 & \\
\hline OT26 & 35.894 & 137.525 & 83.1 & 294.3 & 22.9 & 7 & - & - & 50 & 36 & $\neq, *$ \\
\hline OT37 & 35.898 & 137.525 & 71.5 & 342.5 & 5.0 & 6 & 66.5 & 112.7 & 4.2 & 1.2 & (2) \\
\hline OT38 & 35.899 & 137.533 & 67.6 & 343.4 & 7.3 & 6 & 71.1 & 103.4 & 2.4 & 0.8 & \\
\hline OT47 & 35.900 & 137.492 & 47.7 & 354.8 & 2.5 & 6 & 81.6 & 350.6 & 3.5 & 0.5 & \\
\hline \multicolumn{12}{|c|}{ - Nigorigo Volcano, $80 \pm 4 \mathrm{ka}-$} \\
\hline OT33 & 35.930 & 137.447 & 63.0 & 104.2 & 3.2 & 16 & 15.9 & 183.3 & 1.1 & 0.4 & \\
\hline OT34 & 35.920 & 137.454 & 49.3 & 354.1 & 3.8 & 6 & 82.4 & 359.8 & 3.1 & 0.6 & \\
\hline \multicolumn{12}{|c|}{ 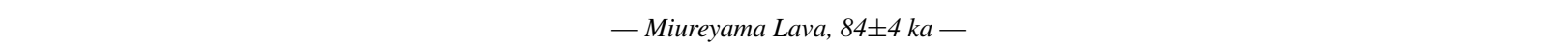 } \\
\hline ОТ06 & 35.889 & 137.468 & 45.5 & 11.9 & 5.5 & 7 & 76.5 & 265.5 & 0.8 & 0.1 & \\
\hline \multicolumn{12}{|c|}{ - Yunotani Lava, $84 \pm 5$ ka- } \\
\hline OT27 & 35.907 & 137.462 & 65.0 & 21.9 & 4.7 & 8 & 70.3 & 186.4 & 1.4 & 0.3 & \\
\hline
\end{tabular}

Note:

Lat, Lon, latitude and longitude of site locality; Inc, Dec, site mean direction; $\alpha_{95}, 95 \%$ confidence circle for the mean direction; N, number of specimens used for the site statistics; Plat, Plon, latitude and longitude of VGP; $\bar{J}, s_{J}$, mean and standard deviation of NRM intensity.

Remark:

*, rejected due to a large $\alpha_{95} ; \dagger$, combined results; $\ddagger$, site mean direction was calculated by the great circle method; (1), the same lava as OT29; (2) possibly the same lava as OT26. 


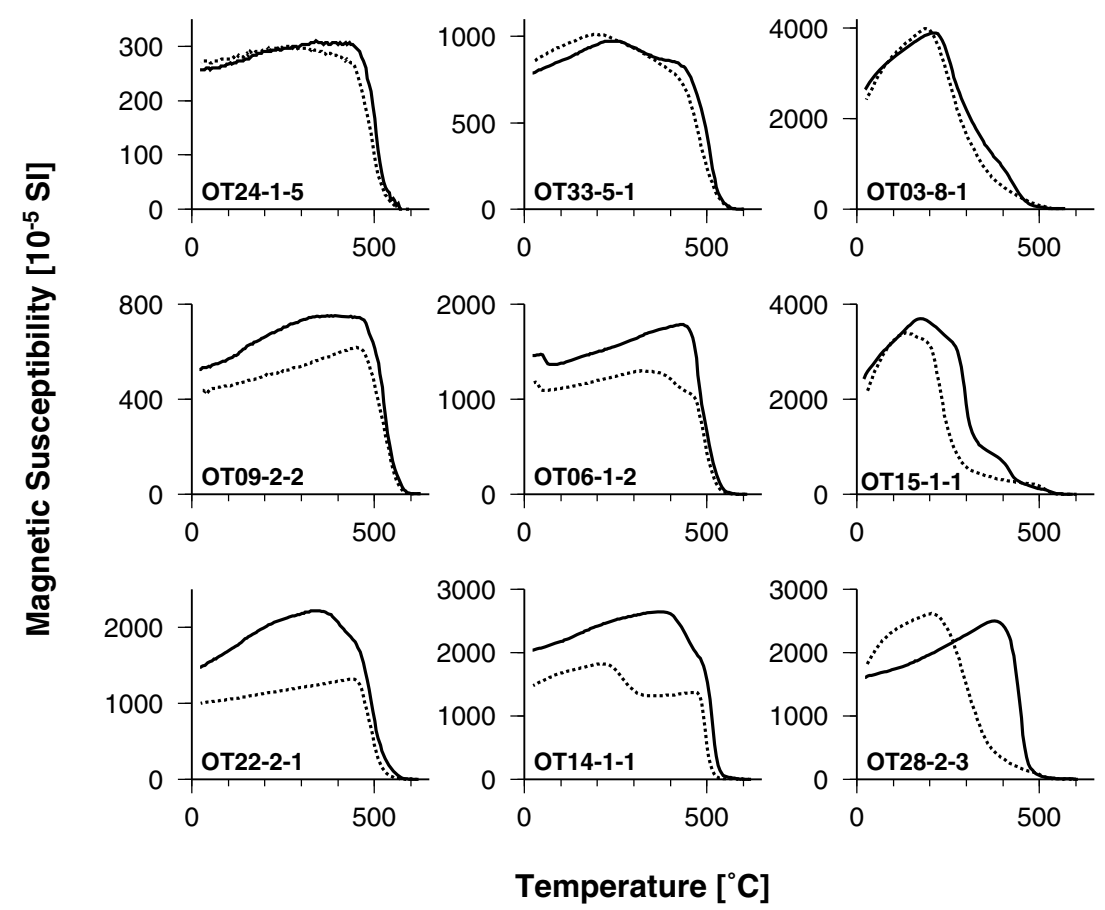

Fig. 6. Representative $\chi$-T curves in which solid and dotted lines indicate heating and cooling runs, respectively. $\chi$-T curves were grouped to three ranks of A (top row), B (middle row), and $\mathrm{C}$ (bottom row) according to the repeatability of the heating and cooling runs.

cause of their VGP positions being lower than $45^{\circ} \mathrm{N}$. One from the $48 \mathrm{ka}$ lava is characterized by slightly deep inclination of $63^{\circ}$ and by easterly deflected declination of $64^{\circ}$. Another one from the $80 \mathrm{ka}$ lava is characterized by similar inclination of $63^{\circ}$ and further easterly deflected declination of $104^{\circ}$. These paleodirections are not much conspicuous with VGP positions which does not go beyond the equator. Nevertheless, identification of these excursions from volcanic rocks is important because they are possibly related to some of the excursions reported for the latest Pleistocene as will be discussed later.

\section{Preliminary Paleointensities}

Paleointensity experiments were made to 36 samples from 6 sites using the Coe's methodology (Coe, 1967) of the Thellier's method (Thellier and Thellier, 1959). Samples were selected based on the stability of remanence to both AF and thermal demagnetizations and the smallness of secondary component. Repeatability of magnetic susceptibility versus temperature $(\chi-\mathrm{T})$ curve between heating and cooling runs was also taken into consideration to the sample selection. The $\chi$-T curves were grouped to three ranks (A, B, and C) according to the repeatability of heating and cooling runs. Representative $\chi$-T curves are shown in Fig. 6 in which three examples from each category are placed from top (class A) to bottom (class C) rows. Only four lavas were grouped to class A, so samples from group B were also used for the paleointensity experiments. Two series of the paleointensity experiments were made first in air and second in vacuum of $\sim 1 \mathrm{~Pa}$, making it possible to experiment in different atmosphere for the same lava.

Results were analyzed on the NRM-TRM diagram or Arai plot (Nagata et al., 1963). Acceptance criteria used in this

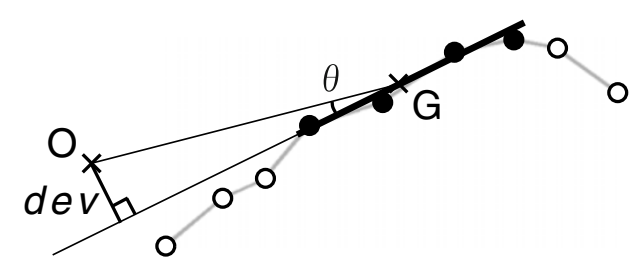

Fig. 7. Two parameters used to judge criterion 4) less ambiguously. The figure represents end points of remanence vectors for zero-field steps, where closed and open circles indicate selected and rejected steps, respectively. Principal component is shown by a thick line and $\mathrm{G}$ is its center of mass where $\mathrm{O}$ is the origin. Actual dev used is normalized by the NRM intensity.

study are 1) at least four data points are included in the linear segment, 2) correlation coefficient of the segment should be larger than $0.98,3$ ) no indication of VRM in the orthogonal plot of zero field steps which correspond to the linear segment, 4) similarly no indication of TCRM judged by that the corresponding zero field steps decrease toward the origin of the orthogonal plot, 5) pTRM test within the linear segment gives a positive result of less than $5 \%$ of the total TRM which is defined as the extrapolated TRM on the Arai plot, and 6) room temperature magnetic susceptibility should remain within $20 \%$ of the original value for the temperature range of the linear segment.

To judge the criterion 4) less ambiguously, two parameters were introduced; difference angle $(\theta)$ and deviation (dev) described in Fig. 7. $\theta$ is the difference angle between the principal component corresponding to the selected linear segment (thick line) and the direction of their center of mass (G). dev is the minimum distance of the extension of the principal component from the origin, divided by the NRM intensity which is defined as the extrapolated NRM on the Arai plot. 

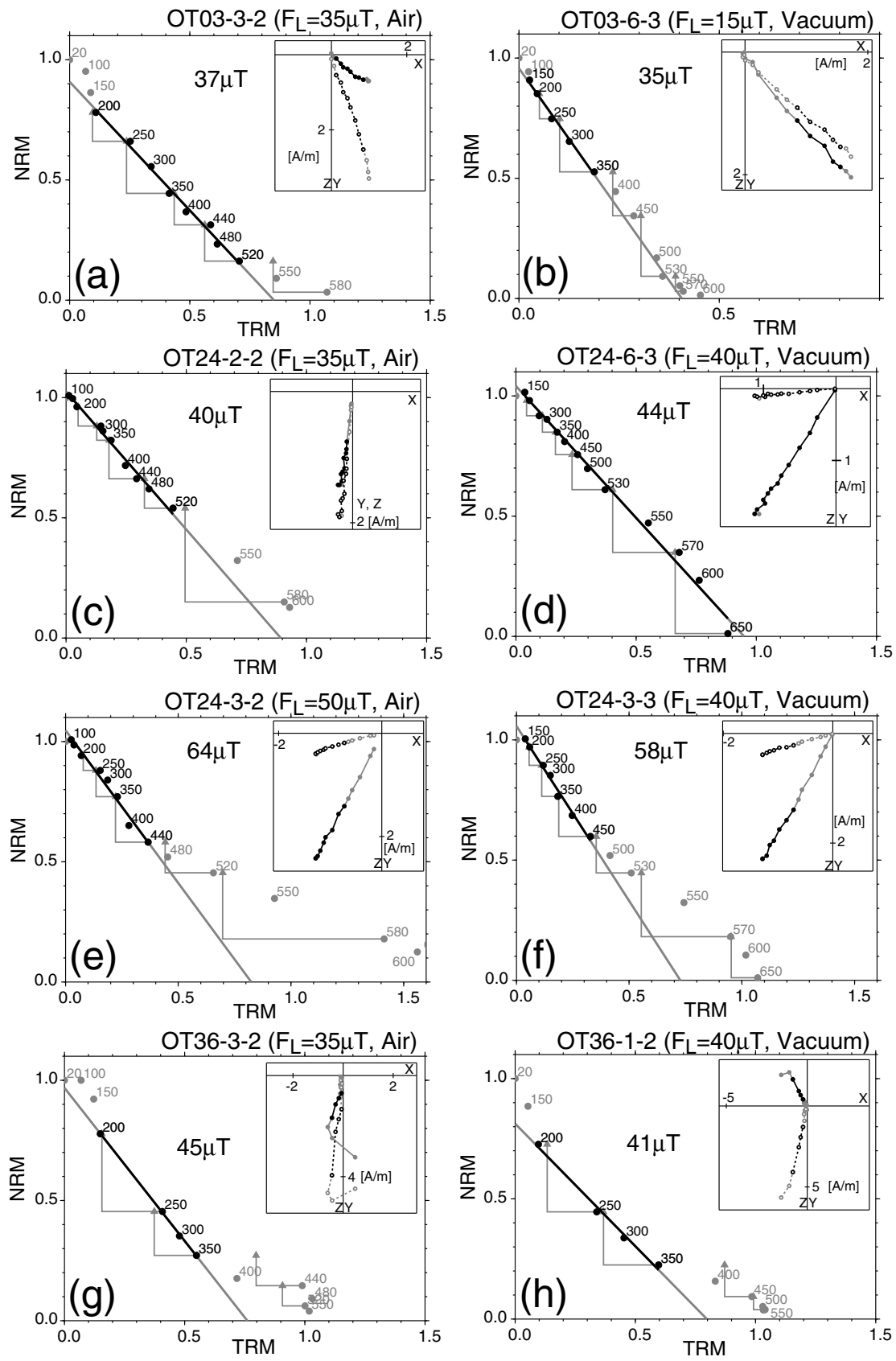

Fig. 8. Examples of successful Arai plot in the Thellier's paleointensity experiment. Inset in each figure shows an orthogonal plot of NRM steps in sample coordinate. The laboratory field was applied to the positive $\mathrm{x}$-axis for the experiments in air, and the positive $\mathrm{z}$-axis for those in vacuum. All data points excluded from the linear segment are shown by dimmed symbols. In the Arai plot, pTRM tests are shown in a dimmed triangle for all steps. Closed and open circles in the orthogonal plot are projections on the X-Y and X-Z planes, respectively.

These parameters have no statistical background and obviously depend on the difference angle between the directions of NRM and the inducing field. Nevertheless they were useful to judge the results less subjectively, and $\theta$ and $d e v$ of less than $10^{\circ}$ and $10 \%$, respectively, were adopted as acceptance criteria. Calculation of the slope of the Arai plot and other quality factors was made following Coe et al. (1978) and the principal component on the orthogonal plot was determined by the method of Kirschvink (1980).

Representative successful Arai plots are shown in Fig. 8. Each diagram includes an inset which shows an orthogonal plot of zero field steps in sample coordinate. The laboratory field was applied to the positive $\mathrm{x}$-axis for the experiments in air, and the positive $\mathrm{z}$-axis for those in vacuum. Two results shown in Fig. 8(a) and (b) were obtained from the same lava (OT03) in different experimental conditions of furnace atmosphere and laboratory field. Although the small laboratory field of $15 \mu \mathrm{T}$ used for OT03-6-3 was originally aimed to experiment on the samples from the lavas of an intermediate paleodirection, good consistency of the result with other OT03 samples shows reliability of the experiments.

Figure 8(c) and (d) show another case of consistent results of about $40 \mu \mathrm{T}$ obtained from the same lava (OT24). This flow is a rhyolite lava which is rare in the Ontake Volcano, but appearance of data points on the Arai plots was not different from those of andesite lavas. Both of two results ob- 

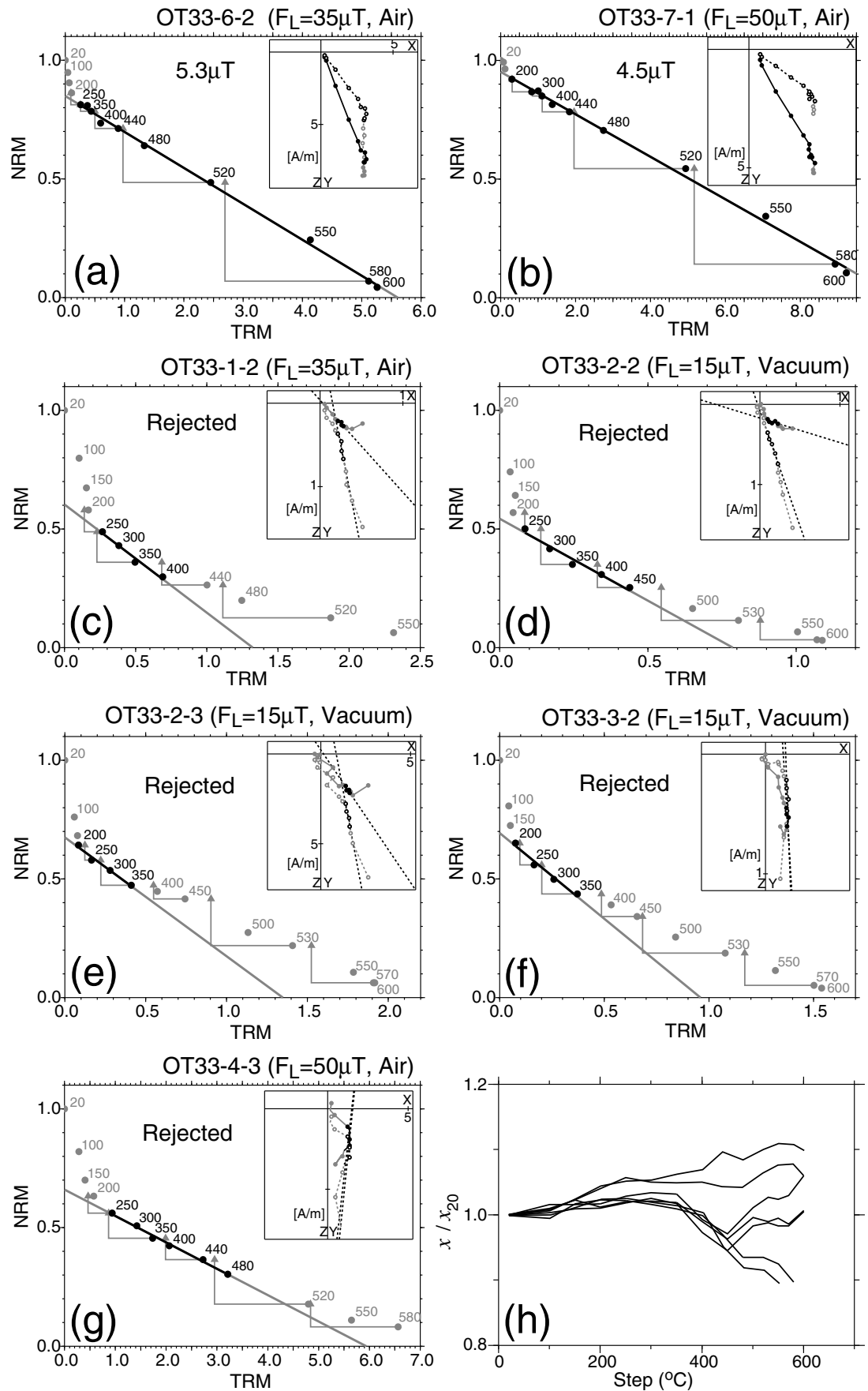

Fig. 9. All Arai plots from the lava flow of the 80 ka excursion. Symbols are the same as those used in Fig. 8. Only two samples out of seven were successful, giving very low paleointensities of about $5 \mu \mathrm{T}$. Normalized $\chi$-step curves are shown for all samples in (h), where the successful two samples correspond to the uppermost two curves which lack in abrupt change of $\chi$ at about $400^{\circ} \mathrm{C}$.

tained in different atmosphere were successful, although the result is better in vacuum than in air. However, much larger paleointensity of about $60 \mu \mathrm{T}$ was obtained from the same lava as shown in Fig. 8(e) and (f). These results were obtained from two specimens of the same core (OT24-3) which were experimented in different atmosphere with a slightly different laboratory field. There is no reason to reject these high values as all acceptance criteria are satisfied and the two results from the same core are consistent. This puzzling result is similar to the case of Hawaii 1960 lava (Tanaka and Kono, 1991) in which one sample gave much higher value than others. Possible interpretation of such inconsistency in the Thellier's experiment would be effect of TCRM which was formed during the original cooling of the lava at the site (Abokhodair, 1977; Yamamoto et al., 2003). In the case of OT24, however, it is difficult to conclude which of the results is an outlier because distinctive samples involved in the experiment were only three although six specimens were used. Hence, all successful results were used to obtain the site mean paleointensity.

Results from the 48 ka lava with an intermediate paleodirection are shown in Fig. 8(g) and (h). No particularly small or large paleointensity was obtained for this intermediate paleodirection. 
Table 2. Sample results of paleointensity experiment.

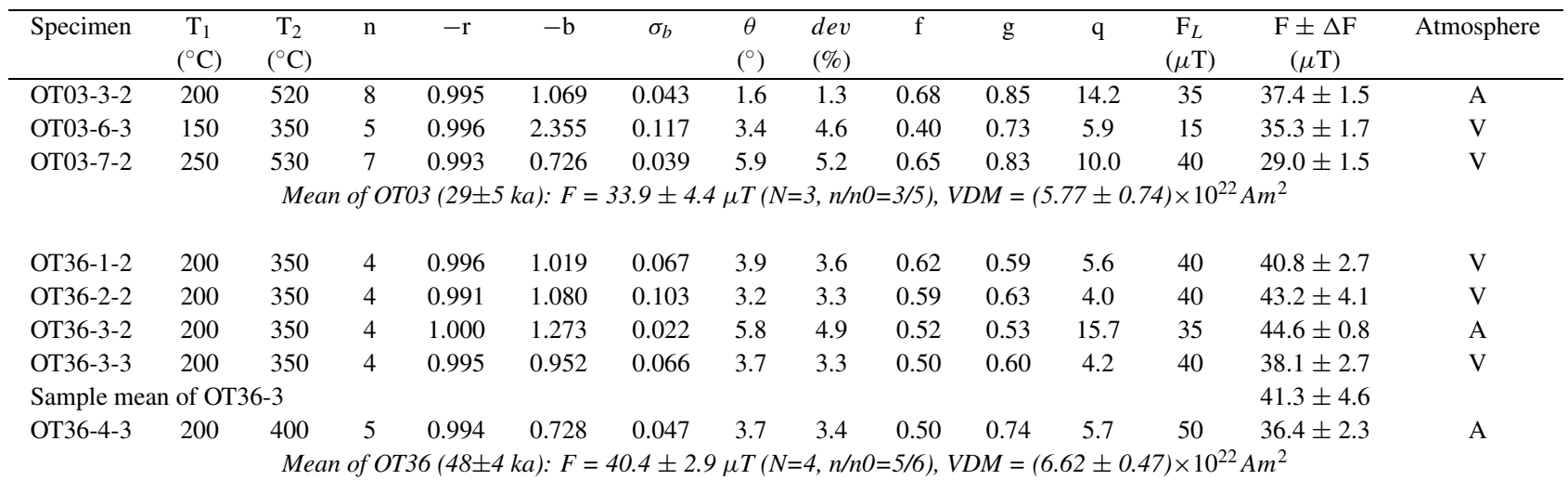

No results from $O T 17(58 \pm 11 \mathrm{ka}): \mathrm{n} / \mathrm{nO}=0 / 5$

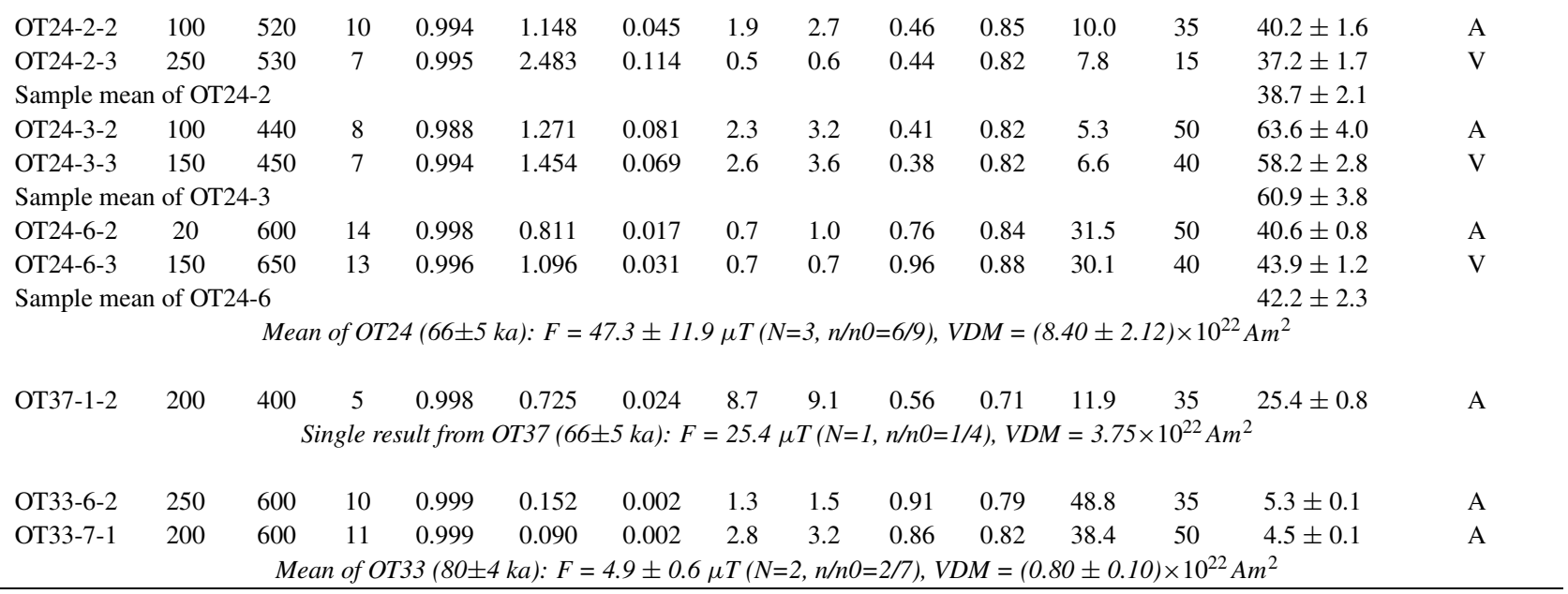

Note: $\mathrm{T}_{1}, \mathrm{~T}_{2}$, lower and upper temperatures for the linear segment; $\mathrm{n}$, number of data point included in the linear regression; $\mathrm{r}$, correlation coefficient of the linear segment; $\mathrm{b}$, slope of the segment; $\sigma_{b}$, standard error of $\mathrm{b} ; \theta$, dev, difference angle and deviation of the selected NRM component from the origin on the orthogonal plot; f, g, q, quality parameters after Coe et al. (1978); $\mathrm{F}_{L}$, laboratory field strength; F, $\Delta \mathrm{F}$, paleointensity and its standard error; Atmosphere, air (A) or vacuum (V).

Site mean is a simple average of the sample paleointensities, and is shown in italic with its standard deviation.

$\mathrm{N}$, number of samples involved in the site mean; $\mathrm{n}, \mathrm{n} 0$, number of specimens accepted and used.

Figure 9 shows all results from another lava with intermediate direction of $80 \mathrm{ka}$. Experiment was successful in only two samples out of seven, giving very small paleointensities of about $5 \mu \mathrm{T}$. The two successful Arai plots are shown in Fig. 9(a) and (b) in which all the acceptance criteria were satisfied. These two results were obtained from the first series of the experiments which was made in air. Unfortunately the experiment was unsuccessful in the second series made in vacuum with a reduced inducing field of $15 \mu \mathrm{T}$ as shown in Fig. 9(d), (e), and (f).

In most unsuccessful samples there was a linear segment in which pTRM test was positive except OT33-2-2 (d) which failed over the whole temperature range. Hence, as known from the orthogonal diagram, the main reason to reject the results was criterion 4) which states no indication of TCRM in the direction of zero-field steps.

Figure 9(h) shows curves of $\chi$ versus temperature step for all samples. This figure simply illustrates that there was no drastic change of $\chi$ for all the samples. Interesting fact, however, is that the $\chi$-step curves for the successful two samples correspond to the uppermost two curves which show gradual increase of $\chi$ with temperature. Five unsuccessful samples, on the other hand, show a rather abrupt decrease of $\chi$ around the step of $400^{\circ} \mathrm{C}$. Possible connection of the kinked $\chi$-step curves to the failure of the Thellier's experiment was also recognized in the Hawaii lavas by Tanaka and Kono (1991).

Details of the sample results of the paleointensity experiments are summarized in Table 2 in which the site mean is a simple average without any weighting.

\section{Discussion}

The ASD of $15.6^{\circ}$ for VGP obtained in this study represents a relatively short time span which is accurately confined between about 20 and $90 \mathrm{ka}$. Nevertheless, the obtained ASD is not different from a typical value for the last 5 my. By analyzing the PSV for the last $10 \mathrm{ky}$, Ohno and Hamano (1993) suggested that a large value of ASD reflects low dipole moment because the level of non-dipole field stayed almost constant during the term they studied. In the past studies, broad paleointensity low was suggested for 20-50 ka (McElhinny and Senanayake, 1982; Tanaka et al., 1994). This suggestion is still correct but accumulation of 

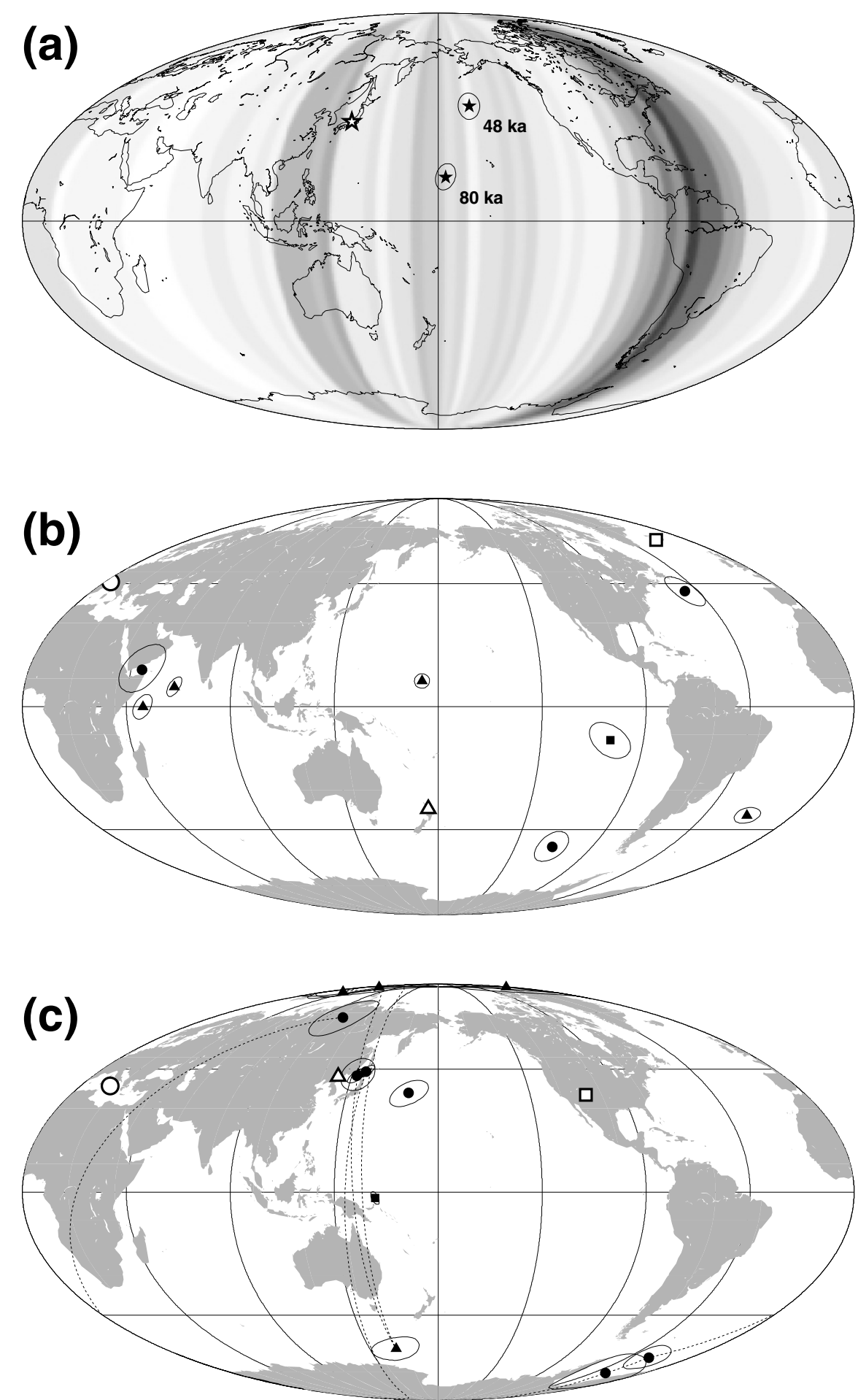

Fig. 10. Plot of VGPs from the $48 \mathrm{ka}$ and $80 \mathrm{ka}$ excursions in this study (a), and those previously reported from lavas for the Laschamp excursion (b) and the Blake excursion (c). VGPs from different sites are shown by different symbols, where larger open ones indicate the site locations. In (b), the VGP positions are overall means except for three sites from New Zealand which are lava means. In (c), all VGPs are lava means and fine dotted lines indicate stratigraphic relations among them. In (a), relative darkness of gray shade shows relative occurrence of the equatorial crossings of the transitional VGP paths from sediments for the last 12 my compiled by Laj et al. (1992). The plots were drawn by the Mollweide projection.

data from volcanic rocks shows quite oscillatory nature of paleointensity in the time range of $40-100 \mathrm{ka}$, and recent review was given by Laj et al. (2002) with many new data from a Hawaii drilled core. Hence the value of ASD from this study for the time span of 20-90 ka which is also typical for the last $5 \mathrm{my}$ is not surprising. Relative paleointensities from sediments also show oscillatory curves for the last
$100 \mathrm{ky}$ although the details of fluctuation are not necessarily consistent with volcanic records (Guyodo and Valet, 1996; Laj et al., 2000). Actually, the preliminary paleointensities obtained in this study, VDM of $3.8-8.4 \times 10^{22} \mathrm{Am}^{2}$, are not necessarily low except for the excursion from the 80 ka lava.

The two intermediate paleodirections found from the 48 ka and 80 ka lavas are characterized by easterly deflected 
declination. These two excursions give VGP positions of $\left(41.9^{\circ} \mathrm{N}, 196.2^{\circ} \mathrm{E}\right)$ and $\left(15.9^{\circ} \mathrm{N}, 183.3^{\circ} \mathrm{E}\right)$, and VDMs of 6.7 and $0.8\left(\times 10^{22} \mathrm{Am}^{2}\right)$ for the former and latter, respectively. Low VGP latitude and small paleointensity obtained from the $80 \mathrm{ka}$ lava is typical for an excursion, while the $48 \mathrm{ka}$ lava is not so conspicuous in paleointensity. Possible excursion from the Ontake Volcano was suggested in the past by Hirooka et al. (1978) from some of the tephra layers. This was also found from ash and loam layers originated from the Yatsugatake Volcano which is $80 \mathrm{~km}$ apart from the Ontake Volcano (Aida, 1978). Comparison of these two studies with our new results was avoided, because consistency of the data from two sections were low in Hirooka et al. (1978) and no magnetic cleaning was involved in Aida (1978). Nevertheless, the general paleodirections of the previous results are similar to ours characterized by easterly deflected declination.

In the review of excursions in the Brunhes chron by Langereis et al. (1997), doubt was shed to the occurrence of excursions from the Lake Biwa, Japan, which were found from $197 \mathrm{~m}$ core drilled in 1972 (Kawai et al., 1972; Nakajima et al., 1973; Yaskawa et al., 1973). Main reason of the negative suggestion to the Lake Biwa excursions is the fact that no excursion was found in the new core of $1422.5 \mathrm{~m}$ length which was drilled near the original site 10 years later (Torii et al., 1983). However, based on updated chronology by Machida et al. (1991), Hyodo and Minemoto (1996) concluded high possibility of occurrence of Lake Biwa excursions by reexamining the old record of the $200 \mathrm{~m}$ Lake Biwa which has some signatures similar to those in marine sediments by Ohno et al. (1993). Further scientific drilling will be necessary to reconcile the possibility of the Lake Biwa excursions.

Although there have been some other indications of excursions for the latest Pleistocene from Japan such as a possible Blake excursion by Manabe (1977) from northeast Japan ${ }^{1}$, all the reports are not conclusive. Hence, finding of intermediate directions from Ontake lavas gives a strong evidence that some of the excursions in the latest Pleistocene reported worldwide were also observed in Japan.

Correlating the two excursions reported in this study to those previously reported worldwide is not necessarily an easy task. Although the K-Ar ages associated with the Ontake lavas are very accurate, there is no stratigraphic confinement from the global age markers such as $\delta^{18} \mathrm{O}$ curves. Statistical error attached to a radiometric age is usually much smaller than the true error. Error of $15 \%$ was suggested by Matsumoto et al. (1989) when an ideal basalt of $0.05 \mathrm{Ma}$ is dated by peak comparison method of K-Ar dating. Considering also a small inconsistency between the stratigraphy and K-Ar ages as shown in Fig. 1 (corrected from the original figure as mentioned in Section 2), a realistic error of the ages would be about 10-15 ky. Hence, the excursion of the $48 \mathrm{ka}$ lava is probably correlated to the Laschamp excursion

1) Another report from the northeast Japan by Tanaka and Tachibana ( $J$. Geomag. Geoelectr., 33, 287-292, 1981) was an error as stated at p. 99 of Jacobs (1984). Correlating the welded tuff layer to a sand and gravel bed which was dated at $22 \mathrm{ka}$ by ${ }^{14} \mathrm{C}$ method was a simple mistake. Since then, K-Ar ages of 0.9-1.2 Ma (Suto, 1982; Tamanyu and Lanphere, 1983) and a fission track age of $716 \mathrm{ka}$ (Machida et al., 1987) were reported for this welded tuff.
(Bonhommet and Zähringer, 1969). On the other hand, the excursion of the $80 \mathrm{ka}$ lava is too young to be correlated to the Blake excursion (Smith and Foster, 1969). Recent studies by marine sediments which incorporate $\delta^{18} \mathrm{O}$ measurements confine the age and duration of the Blake excursion quite accurately as 110-120 ka (ex., Tucholka et al., 1987; Fang et al., 1997). Hence it is incorrect to correlate the $80 \mathrm{ka}$ lava excursion to the Blake excursion. Possible candidates of excursion are the one found from sediments of NorwegianGreenland Sea and Arctic Ocean, which are stratigraphically between the Laschamp and the Blake excursions (Bleil and Gard, 1989; Nowaczyk et al., 1994). This excursion might also be recorded in the $1 \mathrm{~km}$ core of Hawaii lavas by Holt $e t$ al. (1996), because, if the inclination record is carefully examined, anomalously low inclination (No. 32) is recognized between the lavas which correspond to the Laschamp and the Blake excursions.

In the studies of the Blake excursion from lava successions at Island of Lipari, Italy (Zanella and Laurenzi, 1998) and at Jilin, northeastern China (Zhu et al., 2000), it was pointed out that VGP positions came to one of the preferred longitudinal bands of the transitional paths found from sediments (Laj et al., 1991). VGP positions of the $48 \mathrm{ka}$ and $80 \mathrm{ka}$ excursions from this study are rather in the central $\mathrm{Pa}-$ cific region as shown in Fig. 10(a) in which closed and open stars indicate the VGP position and the site location, respectively. In the figure, relative darkness of gray shade shows relative occurrence of the equatorial crossings of the transitional VGP paths for the last 12 my based on the compilation by Laj et al. (1992).

Figure 10(b) shows VGPs from the Laschamp volcanic sites at Shaine des Puys, France (circle), Skalamaelifell, Iceland (square), and Auckland volcanic field, New Zealand (triangle), where open symbols indicate the site location (Roperch et al., 1988; Chauvin et al., 1989; Levi et al., 1990; Shibuya et al., 1992). The VGP positions are overall means except for three sites from New Zealand which are lava means. VGPs from France and Iceland come to the region along north and south America except the one from France which is at the eastern edge of Africa. One site from New Zealand lavas also gave a VGP near South America, and other two sites gave VGPs near eastern Africa which are very close to the one found from France. Most of the anomalous paleodirections from New Zealand gave VGPs at the central Pacific region (in the figure, only the grand mean position is shown), similar to those from the $48 \mathrm{ka}$ and $80 \mathrm{ka}$ lavas in this study.

Figure 10(c) shows the Blake excursion VGPs from lavas at Italy (circle) and China (triangle) which come to the western Pacific region as mentioned before. In the figure, all VGPs are lava means and fine dotted lines indicate stratigraphic relations among them. One VGP shown by a square is the one from $128 \mathrm{ka}$ Laguna basalt, New Mexico, U.S.A. (Champion et al., 1988), which also comes to the western Pacific region.

Similar VGP positions were sometimes observed during excursion from different sites which are far apart on the globe. For the Laschamp excursion, similar VGP positions near the eastern Africa were observed at France and New Zealand as shown in Fig. 10(b). Almost identical VGP po- 
sitions near Japan Island were found from Italy and China during the Blake excursion, although it is difficult to see in Fig. 10(c) due to overlapped symbols. Proximity of the transitional VGPs during excursion indicates a dipole structure of the transitional field. This can be attained by disappearance of the axial dipole field and dominance of the equatorial dipole. Preferred direction of the equatorial dipole is probably related to some kind of features in the core-mantle boundary. The preferred directions seem to include not only the two longitudinal bands of the preferred transitional VGP paths from sediments but also the central Pacific region as found from the Auckland volcanic field, New Zealand and the Ontake Volcano, Japan in this study.

\section{Conclusion}

Angular dispersion obtained from the Younger Ontake Volcano for the accurately confined period of 20-90 ka is not much different from the typical value for the last $5 \mathrm{my}$. In view of the variable feature of paleointensity in the period of 40-100 ka which precedes the global low of 20-40 $\mathrm{ka}$, the obtained typical value of ASD is not surprising. Preliminary paleointensities of $25-47 \mu \mathrm{T}$ obtained in this study from three lavas with ordinary paleodirection are consistent with this. Two low latitude VGPs found from $48 \mathrm{ka}$ and 80 ka andesite lava flows indicate existence of two excursions in Japan during the latest Pleistocene. VGP latitude of the 48 ka excursion is moderately low of $42^{\circ} \mathrm{N}$ and is not accompanied by a low paleointensity, while the VGP latitude and the preliminary paleointensity are $16^{\circ} \mathrm{N}$ and about $5 \mu \mathrm{T}$, respectively, for the $80 \mathrm{ka}$ one. The two excursions found in this study support previous studies of excursion in Japan even though most of them were not conclusive. It is natural to suppose that the $48 \mathrm{ka}$ excursion corresponds to the Laschamp excursion. The $80 \mathrm{ka}$ excursion, on the other hand, is too young to correlate to the Blake excursion even though a realistic error of about $10-15 \mathrm{ky}$ is allowed to the K-Ar age of the lava. Possible candidate to correlate this excursion is the one from sediments of Norwegian-Greenland Sea and Arctic Ocean, which are stratigraphically between the Laschamp and the Blake excursions. Both VGPs from the $48 \mathrm{ka}$ and 80 ka lavas come to the central Pacific region, which is fairly apart from the two preferred bands of the transitional VGP paths from sediments. They are rather close to one of the VGP groups for the Laschamp excursion found from New Zealand lavas.

Acknowledgments. Most of paleomagnetic measurements were made by Mineo Shinozaki, Yasuharu Fukui, and Junko Matsuo of Faculty of Education, Kochi University as their thesis study of B.A. We thank them for their effort in the measurements. A few people joined the field trip; Masaru Kono of Okayama University and Hajime Kitagawa of University of Tokyo for 1997 trip, Tezuka of Toyama University for 1999 trip, and Yuhji Yamamoto of Geological Survey of Japan for 2002 trip. We thank them for all the help in the sample collection. Figure 1 was reproduced from figure 5 of Matsumoto and Kobayashi (1995), although a minor correction was made to an error in stratigraphy. Permission of reproduction was kindly made by Elsevier Science and Akikazu Matsumoto of Geological Survey of Japan. Some of the figures were drawn by a software offered by Hidetoshi Shibuya of Kumamoto University and the Generic Mapping Tools by Wessel and Smith (1998). The original manuscript has greatly improved by many constructive suggestions given by the two reviewers, and for this we thank Andrei
Kosterov of Tokyo Institute of Technology and an anonymous referee. This study was financially supported by Ministry of Education, Culture, Sports, Science, and Technology (MEXT) with a grant-in-aid for scientific research $(12304024,13640424)$. HT also appreciate a partial support from MEXT through the Unzen Scientific Drilling Project (USDP).

\section{References}

Abokhodair, A. A., The accuracy of the Thelliers' technique for the determination of paleointensities of the Earth's magnetic field, Ph.D. Thesis, Univ. of California, Santa Cruz, 346 pp., 1977.

Aida, N., Natural remanent magnetizations and ferromagnetic minerals of the late Pleistocene volcanic ash ("Younger Loam") of the Yatsugatake volcanoes, central Japan, The Quaternary Research, 17, 86-94, 1978 (in Japanese with English abstract).

Bleil, U. and G. Gard, Chronology and correlation of Quaternary magnetostratigraphy and nannofossil biostratigraphy in Norwegian-Greenland Sea sediments, Geologische Rundschau, 78/3, 1173-1187, 1989.

Bonhommet, N. and J. Zähringer, Paleomagnetism and potassium argon age determinations of the Laschamp geomagnetic polarity event, Earth Planet. Sci. Lett., 6, 43-46, 1969.

Champion, D. E., M. A. Lanphere, and M. A. Kuntz, Evidence for a new geomagnetic reversal from lava flows in Idaho: Discussion of short polarity reversals in the Brunhes and Late Matuyama polarity chrons, J. Geophys. Res., 93, 11667-11680, 1988.

Chauvin, A., R. A. Duncan, N. Bonhommet, and S. Levi, Paleointensity of the Earth's magnetic field and K-Ar dating of the Louchadiere volcanic flow (Central France): new evidence for the Laschamp excursion, Geophys. Res. Lett., 16, 1189-1192, 1989.

Coe, R. S., Paleo-intensity of the earth's magnetic field determined from Tertiary and Quaternary rocks, J. Geophys. Res., 72, 3247-3262, 1967.

Coe, R. S., S. Grommé, and E. A. Mankinen, Geomagnetic paleointensities from radiocarbon-dated lava flows on Hawaii and the question of the Pacific nondipole low, J. Geophys. Res., 83, 1740-1756, 1978.

Constable, C. G. and C. L. Johnson, Anisotropic paleosecular variation models: implications for geomagnetic field observables, Phys. Earth Planet. Inter., 115, 35-51, 1999.

Cox, A., Confidence limits for the precision parameter $\kappa$, Geophys. J. R. astr. Soc., 18, 545-549, 1969.

Cox, A., Erratum: Confidence limits for the precision parameter $\kappa$, Geophys J. R. astr. Soc., 48, 136, 1977.

Fang, X.-M., J.-J. Li, R. Van der Voo, C. M. Niocaill, X.-R. Dai, R. A. Kemp, E. Derbyshire, J.-X. Cao, J.-M. Wang, and G. Wang, A record of the blake event during the last interglacial paleosol in the western Loess Plateau of China, Earth Planet. Sci. Lett., 146, 73-82, 1997.

Fisher, R. A., Dispersion on a sphere, Proc. Roy. Soc., A 217, 295-305, 1953.

Guyodo, Y. and J.-P. Valet, Relative variations in geomagnetic intensity from sedimentary records: the past 200,000 years, Earth Planet. Sci. Lett., 143, 23-36, 1996.

Hirooka, K., E. Hasegawa, T. Hirota, S. Nakaya, and T. Yokoyama, On the geomagnetic excursions in the late Pleistocene found in Ontake tephra, Ina, Central Japan, Paleolimnology of Lake Biwa and the Japanese Pleistocene, 6, 101-114, 1978.

Holt, J. W., J. L. Kirschvink, and F. Garnier, Geomagnetic field inclinations for the past $400 \mathrm{kyr}$ from the 1-km core of the Hawaii Scientific Drilling Project, J. Geophys. Res., 101, 11655-11663, 1996.

Hyodo, M. and S. Minemoto, Paleomagnetic dating using geomagnetic secular variations and excursions from lake sediments in Japan, The Quaternary Research, 35, 125-133, 1996 (in Japanese with English abstract).

Jacobs, J. A., Reversals of the Earth's Magnetic Field, 230 pp., Adam Hilger, Bristol, 1984

Kawai, N., K. Yaskawa, T. Nakajima, M. Torii, and S. Horie, Oscillating geomagnetic field with a recurring reversal discovered from Lake Biwa, Proc. Japan Acad., 48, 186-190, 1972.

Kirschvink, J. L., The least-squares line and plane and the analysis of paleomagnetic data, Geophys. J. R. astr. Soc., 62, 699-718, 1980.

Laj, C., A. Mazaud, R. Weeks, M. Fuller, and E. Herrero-Bervera, Geomagnetic reversal paths, Nature, 351, 447, 1991

Laj, C., A. Mazaud, R. Weeks, M. Fuller, and E. Herrero-Bervera, Statistical assessment of the preferred longitudinal bands for recent geomagnetic reversal records, Geophys. Res. Lett., 19, 2003-2006, 1992.

Laj, C., C. Kissel, A. Mazaud, J. E. T. Channell, and J. Beer, North Atlantic palaeointensity stack since $75 \mathrm{ka}$ (NAPIS-75) and the duration of the Laschamp event, Phil. Trans. Roy. Soc. Lond. A., 358, 1009-1025, 2000. 
Laj, C., C. Kissel, V. Scao, J. Beer, D. M. Thomas, H. Guillou, R. Muscheler, and G. Wagner, Geomagnetic intensity and inclination variations at Hawaii for the past $98 \mathrm{kyr}$ from core SOH-4(Big Island): a new study and a comparison with existing contemporary data, Phys. Earth Planet. Inter., 129, 205-243, 2002.

Langereis, C. G., M. J. Dekkers, G. J. de Lange, M. Paterne, and P. J. M. van Santvoort, Magnetostratigraphy and astronomical calibration of the last 1.1 Myr from an eastern Mediterranean piston core and dating of short events in the Brunhes, Geophys. J. Int., 129, 75-94, 1997.

Levi, S., H. Audunsson, R. A. Duncan, L. Kristjansson, P.-Y. Gillot, and S. P. Jakobsson, Late Pleistocene geomagnetic excursion in Icelandic lavas: confirmation of the Laschamp excursion, Earth Planet. Sci. Lett., 96, 443-457, 1990.

Lund, S. P., G. Acton, B. Clement, M. Hastedt, M. Okada, and T. Williams, Geomagnetic field excursions occurred often during the last million years, Eos Tran. Am. Geophys. Union, 79, 178-179, 1998.

Machida, M., K. Okami, N. Doi, and M. Hatamura, Tephrochronology and fission track age of the Shibutami Welded Tuff distributed around Iwate Volcano, Northeast Honshu, Japan, Bull, Saitama Mus. Nat, Hist, 5, 4958, 1987 (in Japanese with English abstract).

Machida, H., F. Arai, and T. Yokoyama, Re-examination of marker-tephra layers in the $200 \mathrm{~m}$ Biwa-Lake core, The Quaternary Research, 30, 439442, 1991 (in Japanese with English abstract).

Manabe, K., Reversed magnetozone in the late Pleistocene sediments from the Pacific coast of Odaka, northeast Japan, Quaternary Research, 7 , 372-379, 1977.

Mankinen, E. A., C. S. Grommé, G. B. Dalrymple, M. A. Lanphere, and R. A. Bailey, Paleomagnetism and K-Ar ages of volcanic rocks from Long Valley caldera, California, J. Geophys. Res., 91, 633-652, 1986.

Matsumoto, A. and T. Kobayashi, K-Ar age determination of late Quaternary volcanic rocks using the "mass fractionation correction procedure" application to the Younger Ontake Volcano, central Japan, Chem. Geol. (Isot. Geosci. Sect.), 125, 123-135, 1995.

Matsumoto, A. and T. Kobayashi, K-Ar ages of the Older Ontake Volcanic products, Ontake Volcano, central Japan: Reappraisal of the volcanic history based on the radiometric data, Bull. Volcanol. Soc. Japan, 44, 1-12, 1999 (in Japanese with English abstract).

Matsumoto, A., K. Uto, and K. Shibata, K-Ar dating by peak comparison method-New technique applicable to rocks younger than $0.5 \mathrm{Ma}-$, Bull. Geol. Surv. Japan, 40, 565-579, 1989.

McElhinny, M. W. and P. L. McFadden, Palaeosecular variation over the past 5 Myr based on a new generalized database, Geophys. J. Int., 131, 240-252, 1997.

McElhinny, M. W. and W. E. Senanayake, Variations in the geomagnetic dipole 1: The past 50000 years, J. Geomag. Geoelectr., 34, 39-51, 1982.

McElhinny, M. W., P. L. McFadden, and R. T. Merrill, The myth of the Pacific dipole window, Earth Planet. Sci. Lett., 143, 13-22, 1996.

McFadden, P. L. and F. J. Lowes, The discrimination of mean directions drawn from Fisher distributions, Geophys. J. R. astr. Soc., 67, 19-33, 1981.

McFadden, P. L. and M. W. McElhinny, The combined analysis of remagnetization circles and direct observations in paleomagnetism, Earth Planet. Sci. Lett., 87, 161-172, 1988.

Nagata, T., Y. Arai, and K. Momose, Secular variation of the geomagnetic total force during the last 5000 years, J. Geophys. Res., 68, 5277-5281, 1963.

Nakajima, T., K. Yaskawa, N. Natsuhara, N. Kawai, and S. Horie, Very short period geomagnetic excursion 18,000 yr BP, Nature, 244, 8-10, 1973.

Nowaczyk, N. R., T. W. Frederichs, A. Eisenhauer, and G. Gard, Magnetostratigraphic data from late Quaternary sediments from the Yermak Plateau, Arctic Ocean: evidence for four geomagnetic polarity event within the last $170 \mathrm{Ka}$ of the Brunhes Chron, Geophys. J. Int., 117, 453$471,1994$.

Ohno, M. and Y. Hamano, Global Analysis of geomagnetic field: time variation of the dipole moment and the geomagnetic pole in the Holocene,
J. Geomag. Geoelectr., 45, 1455-1466, 1993.

Ohno, M., Y. Hamano, M. Murayama, E. Matsumoto, H. Iwakura, T. Nakamura, and A. Taira, Paleomagnetic record over the past 35,000 years of a sediment core from off Shikoku, Southwest Japan, Geophys. Res. Lett., 20, 1395-1398, 1993.

Roperch, P., N. Bonhommet, and S. Levi, Paleointensity of the earth's magnetic field during the Laschamp excursion and its geomagnetic implications, Earth Planet. Sci. Lett., 88, 209-219, 1988.

Shibuya, H., J. Cassidy, I. E. M. Smith, and T. Itaya, A geomagnetic excursion in the Brunhes epoch recorded in New Zealand basalts, Earth Planet. Sci. Lett., 111, 41-48, 1992.

Shibuya, H., J. Cassidy, I. E. M. Smith, and T. Itaya, Paleomagnetism of young New Zealand basalts and longitudinal distribution of paleosecular variation, J. Geomag. Geoelectr., 47, 1011-1022, 1995.

Smith, J. D. and J. H. Foster, Geomagnetic reversal in Brunhes normal polarity epoch, Science, 163, 565-567, 1969.

Suto, S., K-Ar age of the Tamagawa welded tuffs and related rocks from Hachimantai geothermal field, northeast Japan, J. Geothermal Res. Soc. Japan, 4, 159-170, 1982 (in Japanese with English abstract).

Tamanyu, S. and M. A. Lanphere, Volcanic and geothermal history at the Hachimantai geothermal field in Japan-On the basis of K-Ar ages-, $J$. Geol. Soc. Japan, 89, 501-510, 1983.

Tanaka, H. and M. Kono, Preliminary results and reliability of palaeointensity studies on historical and ${ }^{14} \mathrm{C}$ dated Hawaiian lavas, J. Geomag. Geoelectr., 43, 375-388, 1991.

Tanaka, H., A. Otsuka, T. Tachibana, and M. Kono, Paleointensities for 10 22 ka from volcanic rocks in Japan and New Zealand, Earth Planet. Sci. Lett., 122, 29-42, 1994.

Thellier, E. and O. Thellier, Sur l'intensité du champ magnetique terrestre dans le passé historique et géologique, Ann. Geophys., 15, 285-376, 1959.

Torii, M., H. Shibuya, A. Hayashida, I. Katsura, S. Yoshida, T. Tagami, Y. Otofuji, Y. Maeda, and S. Sasajima, Paleomagnetic measurements of deep drilling core samples from Lake Biwa, Rock Mag. Paleogeophys., 10, 33-37, 1983

Tsunakawa, H., Geomagnetic secular variation during the Brunhes epoch inferred from the paleomagnetism and the last 200 years geomagnetic field, J. Geomag. Geoelectr., 40, 1365-1385, 1988.

Tucholka, P., M. Fontugne, F. Guichard, and M. Paterne, The Blake magnetic polarity episode in cores from the Mediterranean Sea, Earth Planet Sci. Lett., 86, 320-326, 1987.

Wessel, P. and W. H. F. Smith, New, improved version of Generic Mapping Tools released, Eos Tran. Am. Geophys. Union, 79, 579, 1998.

Yamada, N. and T. Kobayashi, Geology of the Ontakesan district. With Geological Sheet Map at 1:50,000, Geol. Surv. Japan, 136 pp., 1988 (in Japanese, with English abstract).

Yamamoto, Y., K. Shimura, H. Tsunakawa, T. Kogiso, K. Uto, H. G. Barsczus, H. Oda, T. Yamazaki, and E. Kikawa, Geomagnetic paleosecular variation for the past $5 \mathrm{Ma}$ in the Society Islands, French Polynesia, Earth Planets Space, 54, 797-802, 2002.

Yamamoto, Y., H. Tsunakawa, and H. Shibuya, Paleointensity study of the Hawaiian 1960 lava: implications for possible causes of erroneously high intensities, Geophys. J. Int., 153, 263-276, 2003.

Yaskawa, K., T. Nakajima, N. Kawai, M. Torii, N. Natsuhara, and S. Horie, Palaeomagnetism of a core from Lake Biwa (I), J. Geomag. Geoelectr. 25, 447-474, 1973.

Zanella, E. and M. A. Laurenzi, Evidence for the Blake event in volcanic rocks from Lipari (Aeolian Archipelago), Geophys. J. Int., 132, 149-158, 1998.

Zhu, R., Y. Pan, and R. S. Coe, Paleointensity studies of a lava succession from Jilin Province, northeastern China: Evidence for the Blake event, $J$. Geophys. Res., 105, 8305-8317, 2000.

H. Tanaka (e-mail: hidefumi@cc.kochi-u.ac.jp) and T. Kobayashi 